\title{
Using of Natural Antioxidant for Preparing Pizza
}

\author{
Mohamed R.G. Youssif, Safaa K. Hassen and Jermine S. Fahim
}

Bread and Pasta Research Department, Food Technology Research Institute, Agricultural Research Center, Giza, Egypt.

\author{
Received: 25 Oct. 2019 / Accepted 10 Dec. / Publication date: 30 Dec. 2019
}

\begin{abstract}
The present work was conducted to evaluate the effect of replacement of wheat flour in pizza dough with $1 \%, 2 \%, 3 \%$ and $4 \%$ of broccoli powder, tomato powder and moringa leaves powder as natural sources of antioxidants on nutritional value, rheological characteristics and sensory properties. The results revealed that tomato powder had high values of lipids, ash and contained the high levels of minerals including ( $\mathrm{Na}, \mathrm{K}, \mathrm{P}, \mathrm{Mg}, \mathrm{Cu}$ and $\mathrm{Zn}$ ) compared to broccoli powder and moringa levels powder. The broccoli powder, tomato powder and moringa leaves powder showed significant differences in antioxidant constituents including phenolic, flavonoids ascorbic acid and beta-carotene. The obtained results indicated that, dried broccoli flower had the highest content of vitamin $\mathrm{C}$ being $82.42 \mathrm{mg} / 100 \mathrm{~g}$ followed by moringa leaves powder $19.82 \mathrm{mg} / 100 \mathrm{~g}$ and tomato powder 15.04 $\mathrm{mg} / 100 \mathrm{~g}$, respectively. On the other hand, the highest value of $\beta$-carotene content was in moringa leaves powder being $17.70 \mathrm{mg} / 100 \mathrm{~g}$, followed by tomato powder $1.67 \mathrm{mg} / 100 \mathrm{~g}$ and broccoli powder $1.39 \mathrm{mg} / 100 \mathrm{~g}$. Incorporation of increasing amount of tomato powder and moringa leaves powder from 0 to $4 \%$ increased farinograph water absorption and dough extensibility while, both of dough stability, resistance to extension and dough energy were decreased gradually. Generally, replacement of wheat flour with broccoli powder, tomato powder and moringa leaves powder to processed pizza increased its content of crude protein, lipids, ash, crude fiber and minerals while carbohydrates content decreased compared to control sample. Also, antioxidant content of product including (phenolic, flavonoids, vitamin $C$ and $\beta$-carotene compounds) was increased. Also, the increase was correlated with the percent of broccoli, tomato and moringa leaves powder replacement. Both of hardness, chewiness and gumminess values were gradually increased by increasing the replacement levels with broccoli powder, tomato powder and moringa leaves powder than that of the control pizza sample. Finally, a replacement up to $3 \%$ of broccoli powder, $3 \%$ tomato powder and $2 \%$ moringa leaves powder gives satisfactory overall consumers acceptability and desirable elevation of antioxidant potential.
\end{abstract}

Keywords: Pizza, antioxidants, broccoli powder, Moringa oleifera leaves powder, tomatoes powder, dough rheology, sensory evaluation.

\section{Introduction}

Pizza was introduced in the middle of $20^{\text {th }}$ century. Gradually it gained huge popularity and now a day's it ranks among the world's most widespread fast foods. Pizzas are known for their wide variety and attractive appearance. It is liked by all aged groups especially in youth (Biase and Zacchetti, 1996). Basically, it is a type of flat bread that is leavened chemically or by yeast and containing flavorful toppings depending upon the consumer preference (Yousaf, 2001). Rheological and functional properties of dough play an important role in governing the quality of pizza. Wheat flour is the major ingredient in the production of bread, pizza and rolls (Shewry et al., 1995).

In recent years great interest has been focused on antioxidant vitamins $\mathrm{C}$ and $\mathrm{E}$, phenolics and carotenoids due to their ability to scavenge active oxygen species and free radicals. A large number of epidemiological and clinical studies have shown that a high antioxidant dietary intake is associated with lower incidence of cardiovascular diseases (Kritchevsky, 1999 and Riboli and Norat, 2003) and some types of cancer (Franceschi et al., 1994 and Giovannucci, 1999).

Antioxidants are important in disease prevention in both plants and animals, inhibiting or delaying the oxidation of biomolecules by preventing the initiation or propagation of oxidizing chain

Corresponding Author: Mohamed R.G. Youssif, Bread and Pasta Research Department, Food Technology Research Institute, Agricultural Research Center, Giza, Egypt.

E-mail: dr.mohamed_rashad@yahoo.com 
reactions (Velioglu et al., 1998). Synthetic antioxidants require extensive and expensive tests to ascertain their safety for food applications, and for this reason, there is interest in the use of naturally occurring antioxidants (Frankel, 1995). The consequent search for natural replacements for synthetic antioxidants has led to the evaluation of a number of plant sources (Heinonen et al., 1998). Fruits and vegetables contain numerous different compounds, many of which have antioxidant properties. These include ascorbic acid, $\alpha$-tocopherol, carotenes and a wide variety of phenolic compounds (Hanldelman, 1996).

Oxidative stress represents an imbalance between the production and manifestation of reactive oxygen species and a biological system's ability to readily detoxify the reactive intermediates or to repair the resulting damage. Oxidative stress may not only be associated with decreased antioxidant levels but also excessive production of oxidants (free radicals) like reactive oxygen species (Canaud et al., 1999 and Sies, 1997).

Broccoli is one of the most commonly consumed green vegetables. Like other species of the Brassica family, broccoli is a source of health-promoting phytochemicals. Broccoli is known mainly for its wide range of bioactive compounds and is rich in both nutritional and non-nutritional antioxidants, including vitamin $\mathrm{C}$, vitamin $\mathrm{E}$, and phenolic compounds including flavonoids, carotenoids, and glucosinolates (Lin and Chang, 2005) which possess both antioxidant and anticancer activities (Gundgaard et al., 2003 and Podsedek, 2007). Glucosinolates constitute a major group of natural plant compounds in the family Brassicaceae. They are responsible for the hot and pungent flavor of crucifers and exhibit anti-cancer activity (Fahey et al., 2001). Glucosinolates can be used as an alternative to synthetic pesticides for pest and disease control (Kirkegaard and Sarwar, 1998). Vitamin $\mathrm{C}$ is a health-promoting antioxidant compound that protects against cell death, directly scavenges superoxide radicals, hydrogen peroxide singlet oxygen, and hydroxyl radicals (Gliszczynska-Swiglo et al., 2006) and cooperates with vitamin E to regenerate membrane-bound oxidized $\alpha$-tocopherol, creating an "antioxidant network" (Valko et al., 2006). Phenolic compounds are secondary metabolites that can neutralize or quench free radicals (Picchi et al., 2012). Flavonoids and their derivatives are the largest group of plant polyphenols (Hounsome et al., 2009). They possess strong antioxidant activity due to their ability to scavenge reactive oxygen species and inhibit oxidative stress (Pourcel et al., 2007).

Moringa oleifera commonly known as "Miracle Tree" or "Mother's Best Friend" is the best known and most widely distributed species of Moringaceae family, having an impressive range of medicinal uses with high nutritional value throughout the world. It is popularly known as drumstick tree, was utilized by the ancient Romans, Greeks and Egyptians. All parts of the Moringa tree are edible and have long been consumed by humans, and their anti-oxidant concentrations warrant the plant's image as a "healthy" food source (Fahey et al., 2004 and Farooq et al., 2012).

Moringa leaves have been reported to be a rich source of $\beta$-carotene, protein, vitamin $C$, calcium and potassium and act as a good source of natural antioxidant due to the presence of ascorbic acid, flavonoids, phenolics and carotenoids. Moringa oleifera contains nitrile mustard oil glycosides and thiocarbamate glycosides which are anti-hypertensive and are very rare in nature (Faizi et al., 1995). The leaves are a rich source of essential amino acids such as methionine, cysteine, tryptophan, and lysine and can be a good source of natural antioxidants (Pari et al., 2007).

Tomatoes are one of the most widely used and versatile vegetable crops. They are consumed fresh and are also used to manufacture a wide range of processed products (Madhavi and Salunkhe, 1998). Tomatoes and tomato products are rich in health-related food components as they are good sources of carotenoids (in particular, lycopene), ascorbic acid (vitamin C), vitamin E, folate, flavonoids and potassium (Beecher, 1998 and Leonardi et al., 2000). Other constituents are protein and dietary fiber (Davies and Hobson, 1981). The chemical composition of the tomato fruit depends on such factors as cultivar, maturity and the environmental conditions in which they are grown (Giovanelli et al., 1999; Abushita et al., 2000 and Thompson et al., 2000).

Regular consumption of tomatoes has been correlated with a reduced risk of various types of cancer (Gerster, 1997 and Weisburger, 1998) and heart diseases (Pandey et al., 1995 and Lavelli et al., 2000). These positive effects are believed to be attributable to the antioxidants, particularly the carotenoids, flavonoids, lycopene and $\beta$-carotene (Lavelli et al., 2000). Furthermore, recommendations to increase daily intake of fruits and vegetables rich in nutrients such as carotenoids and vitamins $\mathrm{C}$ and $\mathrm{E}$ to lower the risk of cancer and cardiovascular diseases have been made by the 
American Cancer Society (1984); Block et al. (1992) and the World Cancer Research Fund (1997). Giovannucci (1999) reviewed a number of epidemiological studies and concluded that the intake of tomato products was consistently associated with a lower risk of a variety of cancers and in particular prostate cancer.

The objective of this study was to improve some existing food resources through their transformation into functional food products such as pizza fortified with using three plant sources rich in natural antioxidants broccoli powder, Moringa oleifera leaves powder and tomatoes powder at various ratios and study the effect of addition of the above mentioned sources on the antioxidants content as well as the sensory quality, natural and chemical characteristics of the final product.

\section{Materials and Methods}

\section{Materials:}

Moringa oleifera leaves were obtained from Agriculture Research Center, Giza, Egypt, while broccoli and tomato were purchased from local market in Giza. Wheat flour $72 \%$ extraction rate was obtained from Five Stars Flour Mills Company, Suez, Egypt. Corn oil, salt, sugar and instant active dry yeast were obtained from the local market.

\section{Methods:}

\section{Preparation of plant samples:}

The fresh, green, undamaged, non-insect infested Moringa oleifera leaves were separated from the stalks of the ties, it was then removed from the leaf petal by hand. The leaves were washed thoroughly three times with plenty of water to remove all the adhering dust, dirt and particles. The leaves were spread on cotton sheet and then covered with netted cloth to keep off insects and dust. The cotton sheet was now placed in direct sunlight away from animals and turned occasionally to ensure even drying. The leaves were turned over several times with hand to improve uniform drying. The leaves were sun-dried for five days. The dried samples were grinded into fine powder and sieved through 60 mesh sieves to get moringa leaf powder according to Nwakalor (2014).

Fresh broccoli flowers (Brassica olearacea L.) were washed by tap water and then, cut into small pieces using a stainless steel knife. Broccoli pieces were spread on aluminum foil-covered trays and kept in hot air drier. The temperature of hot air drier was set to $60 \pm 2^{\circ} \mathrm{C}$ for 24 hours. The dried broccoli sample was grinded into fine powder and sieved through 60 mesh sieves to get broccoli powder according to Ashoush et al. (2017).

Fresh, mature and ripe tomatoes (Lycopersicum esculentum) were purchased from a local market in Giza. The fresh tomatoes were sorted, graded and washed by tap water and then, slicing them cross-sectionally to $1 / 4^{\text {th }}$ of inch thickness using a stainless steel knife. Tomato slices were spread on aluminum foil-covered trays and kept in hot air drier. The temperature of hot air drier was set to $60 \pm 2^{\circ} \mathrm{C}$ for 24 hours. The dried tomato sample was grinded into fine powder and sieved through 60 mesh sieves to get tomato powder according to Bashir et al. (2014).

\section{Preparation of blends:}

Different blends were prepared by, partially substituting of wheat flour by $1,2,3$ and $4 \%$ of moringa leaves, broccoli or tomato powder to prepare different blends which used in preparation of experimental samples of pizza.

\section{Preparation of Pizza:}

Pizza samples were prepared using the straight-dough method according to Pacheco de Delahaye et al. (2005) with some modification; the materials used to produce the control pizza dough included: $100 \mathrm{~g}$ wheat flour, $2 \mathrm{~g}$ instant active dry yeast, $14 \mathrm{~g}$ corn oil, $1 \mathrm{~g}$ salt, $2 \mathrm{~g}$ sugar, and water (was added according to farinograph water absorption). Pizza dough's were prepared by mixing all ingredients in mixing bowl until they reached maximum development. The resulted dough's were let to rest for $20 \mathrm{~min}$ at $30 \pm 2^{\circ} \mathrm{C}$ (first proofing) then the dough's were divided into $150 \mathrm{~g}$ pieces, handrounded and put into pans for final proofing at $30 \pm 2^{\circ} \mathrm{C}$ and $80-85 \%$ relative humidity in fermentation cabinet for $60 \mathrm{~min}$. Then baked in electrically heated oven with steam added during baking at 210 $220^{\circ} \mathrm{C}$ for $10-15 \mathrm{~min}$. After baking, pizza samples were separated from the metal pan and allowed to 
cool at room temperature before sealed in polyethylene bags to prevent moisture loss until the analysis.

\section{Analytical methods:}

Moisture, ash, crude fiber, lipids and nitrogen contents were determined according to the method described in A.O.A.C. (2000). The protein content was calculated by multiplying total nitrogen percentage by 5.70. Lipids were extracted in Soxhlet apparatus using N-hexane as a solvent. The Nitrogen free extract was calculated by differences.

The samples were wet acid-digested, using a nitric acid and perchloric acid mixture (HNO3: $\mathrm{HClO}_{4}, 5: 1 \mathrm{w} / \mathrm{v}$ ) according to the method described by Chapman and Pratt (1978). Then the total amounts of $\mathrm{K}, \mathrm{Na}, \mathrm{Ca}, \mathrm{Mg}, \mathrm{Fe}, \mathrm{Zn}$ and $\mathrm{Mn}$ in the digested samples were determined by atomic absorption spectrophotometry. Whereas phosphorus was determined by spectrophotometer according to the method of Astm (1975).

\section{Rheological Characteristic:}

\section{Farinograph test:}

Water absorption, arrival time, dough development time, dough stability and degree of softening were measured using Farinograph (Brabender Duis Bur G, type 810105001 No. 941026 made in West Germany) according to the method of A.A.C.C. (2000).

\section{Extensograph test:}

Dough extensibility, dough resistance to extension (Elasticity), proportional number, dough energy were measured using Extensograph (Barabender Duis Bur G type 860001 No. 946003 made in West Germany) according to the method described in the A.A.C.C. (2000).

\section{Texture profile analysis of baked pizza:}

Texture profile analysis was conducted by Brookfiled CT3 Texture Analyzer (version2.1, 1000 gram unit). Parameters were automatically recorded by computer software (TA-CT-PRO software). According to A.A.C.C. (2000) the samples $(2.5 \mathrm{~cm}$ height and $4 \mathrm{~cm}$ diameter) were compressed twice to $40 \%$ deformation using Prope- $36 \mathrm{~mm}$ Cylindrical, trigger load $5 \mathrm{~N}$, and test speed- $2 \mathrm{~mm} / \mathrm{s}$. The experiments were conducted under ambient conditions.

Fractionation and quantitative determination of some antioxidant compound by HPLC:

Determination of phenolic compounds:

Phenolic compounds were fractionated and determined by HPLC according to the method of Goupy et al. (1999).

\section{Determination of flavonoids compounds:}

Flavonoids compounds were fractionated and determined by HPLC according to the method of Zuo et al. (2002).

\section{Determination of vitamin C (Ascorbic acid):}

Ascorbic acid was determined by HPLC according to the method of Shimada and Ko, (2006).

\section{Determination of carotenoids:}

Carotene was determined by HPLC according to the method of Khalil and Varananis, (1996).

\section{Determination of lycopene:}

Five grams of the homogenized samples were weighed in a $125 \mathrm{~mL}$ Erlenmeyer flask, which was wrapped in aluminum foil for protection against the light. Fifty milliliter of a mixture of hexane/acetone/ethanol $(2: 1: 1, \mathrm{v} / \mathrm{v} / \mathrm{v})$ was added to solubilize the carotenoids (Sadler et al., 1990). The samples were stirred for 30 minutes and transferred to a separation funnel, and then $10 \mathrm{~mL}$ of distilled water was added. The solution was separated into a polar fraction $(35 \mathrm{~mL})$ and a polar fraction $(25 \mathrm{~mL})$, the latter containing lycopene. The extraction residue did not present coloration. The lycopene content was determined by reading the hexane solution absorbance at $472 \mathrm{~nm}$. The 
conversion of the absorbance into lycopene concentration was based on the specific extinction coefficient for the pigment in hexane (3.450) (Gross, 1987). The results were expressed as $\mathrm{mg}$ of lycopene per $100 \mathrm{~g}$ of sample in dry basis.

\section{Sensory evaluation of pizza:}

Ten panelists from the staff-member at Bread and Pasta Research Department, Food Technology Research Institute, Agricultural Research Center, Giza, Egypt, were evaluated the sensory characteristics of pizza. Pizza samples were elaborated using the defrosted pizza. The sensorial attributes evaluated were crust color, taste, odor, texture (represented by hardness, and chewing action) and general appearance according to Pacheco de Delahaye et al. (2005).

\section{Statistical analysis:}

Data were analyzed by Analysis of Variance using General Liner Model (GLM) procedure according to the procedure reported by Sendecor and Cochran (1997). Means were separated using Duncan's test at a degree of significance $(\mathrm{P} \leq 0.05)$. Statistical analyses were made using the producer of the SAS software system program (SAS, 1997).

\section{Results and Discussions}

\section{Chemical composition:}

The proximate chemical composition of wheat flour, broccoli powder, tomato powder and moringa leaves powder are presented in Table (1). The obtained results revealed that broccoli powder and moringa leaves powder recorded the highest crude protein content being 32.75 and $27.81 \%$, respectively, while strong wheat flour (72\% ext.) had lower crude protein content being $11.82 \%$. On the other hand, the highest value of lipid was recorded for tomato powder, followed by broccoli powder and moringa leaves powder being $4.36,4.10$ and $2.53 \%$, respectively.

Table 1: Proximate chemical composition of wheat flour, broccoli powder, tomato powder and moringa leaves powder ( $\%$ on dry weight basis).

\begin{tabular}{|c|c|c|c|c|}
\hline Parameters & $\begin{array}{c}\text { Wheat flour } \\
\text { (72\% extraction) }\end{array}$ & Broccoli powder & $\begin{array}{l}\text { Tomato } \\
\text { powder }\end{array}$ & $\begin{array}{c}\text { Moringa leaves } \\
\text { powder }\end{array}$ \\
\hline \multicolumn{5}{|c|}{ *Chemical composition $(\%)$} \\
\hline Lipids & $0.63 \pm 0.06$ & $4.10 \pm 0.02$ & $4.36 \pm 0.01$ & $2.53 \pm 0.04$ \\
\hline Ash & $0.62 \pm 0.02$ & $13.41 \pm 0.01$ & $18.45 \pm 0.14$ & $13.24 \pm 0.08$ \\
\hline Crude fiber & $0.92 \pm 0.04$ & $13.65 \pm 0.06$ & $16.50 \pm 0.02$ & $17.10 \pm 0.10$ \\
\hline
\end{tabular}

\begin{tabular}{|c|c|c|c|c|}
\hline \multicolumn{5}{|c|}{ 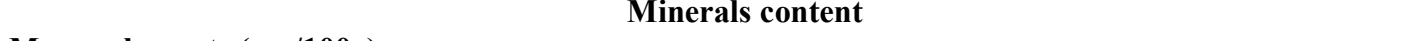 } \\
\hline \multicolumn{5}{|c|}{ Macro elements (mg/100g) } \\
\hline $\mathbf{N a}$ & 42.20 & 24.00 & 134.00 & 16.10 \\
\hline $\mathbf{K}$ & 153.70 & 340.00 & 1927.00 & 1320.00 \\
\hline $\mathbf{C a}$ & 11.20 & 103.20 & 166.00 & 945.30 \\
\hline Mg & 35.20 & 75.30 & 178.00 & 88.32 \\
\hline $\mathbf{P}$ & 98.40 & 256.70 & 295.00 & 218.40 \\
\hline \multicolumn{5}{|c|}{ Micro elements (mg/Kg) } \\
\hline $\mathbf{Z n}$ & 0.45 & 0.68 & 1.71 & 1.03 \\
\hline $\mathbf{C u}$ & 0.82 & 1.10 & 1.24 & 0.91 \\
\hline $\mathbf{F e}$ & 0.95 & 6.50 & 4.56 & 24.70 \\
\hline Mn & 1.12 & 2.30 & 1.95 & 2.42 \\
\hline
\end{tabular}

* Means of triplicate \pm SD.

NFE: Calculated by difference.

Meanwhile, strong wheat flour (72\% ext.) had the lowest lipid value being $0.63 \%$. Tomato powder contained the highest ash content $18.45 \%$ followed by broccoli powder $13.41 \%$ and moringa leaves powder $13.24 \%$. While the wheat flour ( $72 \%$ ext.) had the lowest ash content being $0.62 \%$. Moringa leaves powder contained the highest crude fiber content $17.10 \%$ followed by tomato powder $16.50 \%$ and broccoli powder $13.65 \%$. Meanwhile, wheat flour (72\% ext.) had the lowest crude fiber 
content being $0.92 \%$. Strong wheat flour (72\% ext.) recorded the highest value of nitrogen free extract (NFE) followed by tomato powder and moringa leaves powder being 86.01, 47.77 and 39.32 $\%$, respectively. While, broccoli powder had the lowest NFE being $36.09 \%$. These results are in agreement with those of Kahlon et al.(2005); Borowski et al.(2008) and Awad et al.(2012) they showed that gross chemical composition contents of broccoli were as follow: total carbohydrate 41.0 $51.2 \%$, crude protein $24.1-33.2 \%$, crude fiber $12.77-21.1 \%$, total lipids $4.38-5.97 \%$ and total ash $7.11-10.3 \%$ (on dry matter).

Also, from the results presented in the same table, it could be noticed that broccoli powder, tomato powder and moringa leaves powder contained the highest content of $\mathrm{K}, \mathrm{Ca}, \mathrm{Mg}, \mathrm{Na}, \mathrm{P}, \mathrm{Zn}$, $\mathrm{Cu}, \mathrm{Fe}$ and $\mathrm{Mn}$ compared with wheat flour. Concerning to moringa leaves powder, the obtained results revealed that, moringa leaves powder recorded the highest content of $\mathrm{Ca}$, $\mathrm{Fe}$ and $\mathrm{Mn}$ with values of $945.30,24.70$ and $2.42 \mathrm{mg} / 100 \mathrm{~g}$, respectively compared with broccoli powder, tomato powder and wheat flour. The obtained results confirmed with those obtained by Makkar and Becker (1996); Abd El-Fatah et al. (2013) and Faryabidoust et al. (2013).

Fractionation and quantitative determination of some antioxidant compound in broccoli, tomato and moringa leaves powder by HPLC:

\section{Phenolic compounds in broccoli, tomato and moringa leaves powder:}

Phenolic compouned are able to scavenge reactive oxygen species due to their electron donating properties. Their antioxidant effectiveness depends on the stability in different systems, as well as number and location of hydroxyl groups. In many in vitro studies, phenolic compounds demonstrated higher antioxidant activity than antioxidant vitamins and carotenoids (Vinson et al., 1995 and Re et al., 1999).

The following acids were detected in the extract of dried raw broccoli, tomato and moringa leaves and the obtained result presented in Table (2). From this table it was found that, broccoli flowers contained pyrogallol as the main phenolic compound which reached $275.81 \mathrm{mg} / 100 \mathrm{~g}$ and showed high level of e-vanillic, chlorogenic acid, salycilic acid, P-OH-benzoic acid benzoic acid which recorded 13.823, 13.879, 15.237, 16.823, $25.241 \mathrm{mg} / 100 \mathrm{~g}$, respectively. Our results are in agreement with results of Herrmann (1989) found that, broccoli contains chlorogenic acid (4caffeoylquinic and 3-caffeoylquinic), 3-p-coumaroylquinic and glucose esters of acids: caffeic, ferulic and sinapinic. Additionally, Beveridge et al. (2000) identified $p$-coumaric and benzoic acids in broccoli cell wall material. Our results confirmed the presence of ferulic, caffeic and $p$-coumaric acids.

Also, the obtained results of phenolic compounds analysis are nearly similar to those reported by Gawlik-Dziki (2008) and Figueiredo et al. (2015) they found that, phenolics compound contents of broccoli flowers were as follow: cinnamic $4.5 \mathrm{ppm}$, benzoic acid $265.8 \mathrm{ppm}$, pyrogallol $2845.2 \mathrm{ppm}$, ellagic acid $50.8 \mathrm{ppm}$, gallic acid $4.2 \mathrm{ppm}$, chlorogenic acid $139.9 \mathrm{ppm}$, caffeine $61.3 \mathrm{ppm}$ and salycilic acid $158.4 \mathrm{ppm}$. Moreover, Ashoush et al. (2017) they found that, phenolic compounds of broccoli flowers were as follow: pyrogallol $2898.52 \mathrm{ppm}$, followed by benzoic acid, P-OH-benzoic acid, salycilic acid, e-vanillic acid and chlorogenic acid which were 270.76, 183.04, 161.97, 161.95 and $150.79 \mathrm{ppm}$, respectively.

From the same Table it could be noticed that, Chloregenic acid was the predominant polyphenolic present in dried tomato powder $51.95 \mathrm{mg} / 100 \mathrm{~g}$, followed by Caffiec acid that present in moderate concentration $15.93 \mathrm{mg} / 100 \mathrm{~g}$. While data in the same table revealed that Protocatchuic acid, ferulic acid, p-coumaric acid, Gallic acid, Cinnamic acid, vanillic acid and catechin 7.812, 6.281, $5.073,4.11,3.27,3.12$ and $2.34 \mathrm{mg} / 100 \mathrm{~g}$ were present in the lowest abundant levels. These data are in agreement with those obtained by Luthria et al. (2006) which stated that, the three major phenolic acids extracted from two cultivars of tomato were identified as caffeic, $p$-coumaric and ferulic acids. The concentration of caffeic acid ranged from 13.9 to $24.1 \mathrm{mg} / 100 \mathrm{~g}$ of dried tomato sample, and the amount of $p$-coumaric acid was 3.5 to $5.5 \mathrm{mg} / 100 \mathrm{~g}$. The content of ferulic acid was the lowest of the three phenolic acids in all tomato extracts 0.9 to $1.5 \mathrm{mg} / 100 \mathrm{~g}$.

Also, Slimestada and Verheulb (2009) were mentioned the occurrence of ferulic, caffeic and chlorogenic acids in tomato fruit, and also $p$-coumaric acid was detected in a tomato skin extract, whereas trace amounts of vanillic and salicylic acids were found in red tomatoes. They also 
mentioned that Chlorogenic acids and related compounds are the main phenolic compounds besides flavonoids in tomatoes which have a number of beneficial health properties related to their potent antioxidant activity as well as hepatoprotective, hypoglycemic and antiviral activities.

While, Elbadrawy and Sello (2016) showed that, the main phenolic acids identified in tomato peel are caffeic, procatchoic, vanillic, catechein and gallic acid. Their corresponding concentrations were $0.50,5.52,3.31,2.98$ and $3.85 \mathrm{mg} / 100 \mathrm{~g}$, respectively.

Table 2: Quantitative and qualitative analysis of phenolic compounds in broccoli, tomato and moringa leaves powder by HPLC $(\mathrm{mg} / 100 \mathrm{~g})$

\begin{tabular}{lccc}
\hline Phenolic compounds (mg/100g) & Broccoli powder & Tomato powder & Moringa leaves powder \\
\hline Pyrogallol & 44.929 & 136.668 & 106.773 \\
Benzoic acid & 32.733 & 17.051 & 16.664 \\
4-amino-benzoic acid & 1.884 & 1.140 & 1.025 \\
3,4,5-methoxy-cinnamic & 1.357 & 1.666 & 0.181 \\
Protocatchuic acid & 13.618 & 34.848 & 2.886 \\
Catechol & 8.529 & 25.010 & 8.686 \\
Chlorogenic acid & 5.842 & 10.333 & 1.170 \\
Caffeic acid & 70.109 & 15.942 & 15.637 \\
Caffeine & 8.217 & 2.195 & 0.996 \\
Vanillic acid & 1.783 & 6.031 & 1.391 \\
E-vanillic acid & 10.444 & 27.663 & 12.039 \\
Alpha-Coumaric & 13.297 & 0.629 & 0.405 \\
Salycilic acid & 1.854 & 6.452 & 1.739 \\
Gallic acid & 0.979 & 4.119 & 2.732 \\
Ellagic acid & 30.393 & 8.030 & 3.505 \\
P-OH-benzoic acid & 22.795 & 6.318 & 3.031 \\
Catechin & 6.880 & 2.340 & 19.833 \\
Epicatechin & 28.000 & 20.804 & 3.813 \\
Ferulic acid & 4.767 & 2.791 & 1.709 \\
Iso-Ferulic & 3.014 & 2.219 & 1.601 \\
Resveratol & 1.002 & 0.029 & 0.170 \\
Coumarin & 2.188 & 0.882 & 0.289 \\
P-coumaric acid & 2.986 & 1.479 & 0.206 \\
Cinammic acid & 1.854 & 0.327 & 0.220 \\
\hline & & &
\end{tabular}

In the same time, the obtained results given in Table (2) indicated that moringa leaves contained considerable amount of phenolic compounds with an average from 2.102 to $380.52 \mathrm{mg} / 100 \mathrm{~g}$. It is evident from the data that Ellagic acid, caffiec acid and catechin were the predominant polyphenolic present in moringa leaves powder, comparing with other polyphenolic compounds present in moderates concentrations such as Salicylic, Protocatchuic acid and Catechol. While data in the same table revealed that Gallic acid and Cinnamic acid $(\mathrm{mg} / 100 \mathrm{~g})$ were present in the lowest abundant levels. These data are in agreement with those obtained by Mona-Halaby et al. (2013) and Dalia-Kotb et al. (2017).

\section{Flavonoids compounds in broccoli, tomato and moringa leaves powder:}

Flavonoids are important secondary plant metabolites (Koh et al., 2009) that possess strong antioxidant activity due to their ability to scavenge reactive oxygen species and inhibit oxidative stress (Hounsome et al., 2009).

Flavonoids were detected in the extract of dried raw broccoli, tomato and moringa leaves and the obtained result presented in Table (3). From this table it was found that, broccoli flowers contained Hesperidin as the main flavonoid which reached $83.91 \mathrm{mg} / 100 \mathrm{~g}$ as well as high level of Rosmarinic, Luteolin and Naringin, which were amounted of 48.73, 33.93 and $14.84 \mathrm{mg} / 100 \mathrm{~g}$, respectively. But it could be noticed the low level of Rutin, Quercitin, Kaempferol, Naringenin, Hesperetin, Quecetrin and Apigenin, which had values of 2.11, 1.33, 0.28, 2.93, 5.13, 6.69 and 0.48 $\mathrm{mg} / 100 \mathrm{~g}$, respectively.

These results is agreed also with those of Galan et al. (2004) they indicated that flavonoids found in broccoli flowers were naringin 18.3, apigenin 1.8, hesperidin 91.9, rosmarinic acid 49.2, 
luteolin 38.7 and quercetrin $9.3 \mathrm{mg} / 100 \mathrm{~g}$. Also, Ashoush et al. (2017) they indicated that, the content of flavonoids in broccoli flowers were naringin 16.84, apigenin 0.51, hesperidin 87.91, rosmarinic acid 50.93, luteolin 35.93, rutin 2.54, quercitin 1.63, kaempferol 0.38 , hesperetin 5.85, naringenin 3.85 and quercetrin $7.69 \mathrm{mg} / 100 \mathrm{~g}$.

From the same Table it could be noticed that, Querctin was the abundant flavonoid compounds in dried tomato powder, which were at concentration of $43.32 \mathrm{mg} / 100 \mathrm{~g}$. While, Naringenin and Rutin were the moderate abundant flavonoid compounds in dried tomato powder being 12.26 and 10.97 $\mathrm{mg} / 100 \mathrm{~g}$ and the lowest abundant were Kaempferol and Myricetin being 1.379 and $0.632 \mathrm{mg} / 100 \mathrm{~g}$, respectively.

These findings are in agreement with Martinez-Valverde et al. (2002) who mentioned that, tomato contains quercetin, naringenin, rutin and chlorogenic acid as the main flavonoid compounds. Also, Tokuşoğlu et al. (2003) they determined the amounts of three flavonoids, quercetin, kaempferol, and myricetin, in tomatoes and tomato-based products produced in Turkey by reversed phase highperformance liquid chromatography with UV detection. They concluded that tomatoes and tomatobased products contained primarily quercetin, kaempferol, and the minor flavonol myricetin.

Meanwhile, Martí et al. (2016) stated that, Quercetin is the main flavonol and one of the most important flavonoids from tomato, its content varies from 0.7 to $4.4 \mathrm{mg} / 100 \mathrm{~g}$ fresh weight in different tomato types. The flavanone naringenin is present at lower concentrations, up to $1.3 \mathrm{mg} / 100$ $\mathrm{g}$ fresh weight. It can also be found in its glycosylated form as rutin, with concentrations up to 4.5 $\mathrm{mg} / 100 \mathrm{~g}$. Other flavonols such as kaempferol and myricetin are found in small quantities or traces in cultivated tomato.

Table 3: Quantitative and qualitative analysis of flavonoids compounds in broccoli, tomato and moringa leaves powder by HPLC (mg/100g)

\begin{tabular}{lccc}
\hline Flavonoids compounds (mg/100g) & Broccoli powder & Tomato powder & Moringa leaves powder \\
\hline Rosmarinic & 23.03 & 2.11 & 1.44 \\
Rutin & 2.11 & 10.97 & 21.43 \\
Quercitin & 1.33 & 43.32 & 130.02 \\
Quecetrin & 6.69 & 1.41 & 28.87 \\
Kaempferol & 0.28 & 1.38 & 0.84 \\
Apigenin & 0.48 & 0.50 & 1.33 \\
Hesperetin & 5.13 & 10.82 & 7.74 \\
Hesperidin & 83.91 & 71.97 & 8.15 \\
Luteolin & 33.93 & 16.65 & 19.68 \\
Naringin & 14.84 & 35.76 & 25.86 \\
Naringenin & 2.93 & 12.26 & 3.18 \\
\hline
\end{tabular}

In the same time, the obtained results given in Table (3) indicated that moringa leaves contained considerable amount of flavonoid compounds. It is evident from the data that, Quercitrin and Querctin were the abundant flavonoid compounds, which were at concentration of 288.74 and $130.02 \mathrm{mg} / 100 \mathrm{~g}$, respectively. While, Rutin $21.43(\mathrm{mg} / 100 \mathrm{~g})$ was the moderate abundant flavonoid compounds in moringa leaves powder and the lowest abundant were Rosmarinic acid 2.895 and Kampferol 0.840 $\mathrm{mg} / 100 \mathrm{~g}$, respectively.

According to Lako et al. (2007) they published that, the flavonol quercetin is found at concentrations as high as $100 \mathrm{mg} / 100 \mathrm{~g}$ of dried moringa leaves. Quercetin is a potent antioxidant with multiple therapeutic properties it has shown anti-dyslipidemic, hypotensive, and anti-diabetic effects in the obese rat model of metabolic syndrome. These findings are in agreement with MonaHalaby et al. (2013) and Dalia-Kotb et al. (2017).

\section{Vitamin C, $\beta$-Carotene and lycopene content of broccoli, tomato and moringa leaves powder:}

Vitamin $\mathrm{C}$, which includes ascorbic acid and its oxidation product dehydroascorbic acid, has many biological activities in human body. Block et al. (2004) have found that, vitamin $\mathrm{C}$ can reduce levels of C-reactive protein (CRP), a marker of inflammation and possibly a predictor of heart disease. More than $85 \%$ of vitamin $\mathrm{C}$ in human diets is supplied by fruits and vegetables (Davey et al., 2000 and Lee and Kader, 2000). Biological function of L-ascorbic acid can be defined as an enzyme cofactor, a radical scavenger, and as a donor or acceptor in electron transport at the plasma membrane. 
Ascorbic acid is able to scavenge the superoxide and hydroxyl radicals, as well as regenerate $\alpha$ tocopherol (Davey et al., 2000). Also, Vitamin C is a less stable nutrient due to its high sensitivity to oxidation under the influence of heat and light therefore it degrades rapidly after harvest and during storage Balan et al. (2016).

As shown in table (4), results indicated that, dried broccoli flower had the highest content of vitamin $\mathrm{C}$ being $82.42 \mathrm{mg} / 100 \mathrm{~g}$ followed by moringa leaves powder $19.82 \mathrm{mg} / 100 \mathrm{~g}$ and tomato powder $15.04 \mathrm{mg} / 100 \mathrm{~g}$, respectively.

Those values were in agreement with that reported for broccoli by Kaur et al. (2007) they mentioned that among vegetables, broccoli is an excellent source of vitamin $\mathrm{C}$ and exceeded more than $100 \%$ recommended dietary allowance (RDA) values for vitamin C content ranged from 74.24 to $112.42 \mathrm{mg} / 100 \mathrm{~g}$.

$\beta$-Carotene is a pro-vitamin A and it can be converted into retinol in the intestine and other tissues (Tang, 2010). Retinol is essential for general growth, visual function and embryonic development, as well as in epithelial tissues differentiation. In humans, the Recommended Dietary Allowance (RDA) of vitamin A is 900 and $700 \mu \mathrm{g} /$ day (expressed as retinol equivalents) for male and female adults, respectively, corresponding to $5,400 \mu \mathrm{g}$ /day and 4,200 $\mu \mathrm{g} /$ day of $\beta$-carotene equivalents (Trumbo et al., 2001).

Table 4: Vitamin C, $\beta$-Carotene and lycopene content of broccoli, tomato and moringa leaves powder by HPLC $(\mathrm{mg} / 100 \mathrm{~g})$

\begin{tabular}{lccc}
\hline Compounds (mg/100g) & Broccoli powder & Tomato powder & Moringa leaves powder \\
\hline Vitamin C & 82.42 & 15.04 & 19.82 \\
及-Carotene & 1.39 & 1.67 & 17.70 \\
Lycopene & ND & 32.83 & ND \\
\hline
\end{tabular}

ND: Not determined

On the other hand, results recorded that, the highest value of $\beta$-carotene content was in moringa leaves powder being $17.70 \mathrm{mg} / 100 \mathrm{~g}$, followed by tomato powder $1.67 \mathrm{mg} / 100 \mathrm{~g}$ and broccoli powder $1.39 \mathrm{mg} / 100 \mathrm{~g}$. Those values were in agreement with De Sa and Rodriguez-Amaya (2004) found that, $\beta$-carotene content in broccoli was ranged from 1.24-1.92 mg/100g of dry weight. Also, Kaur et al. (2007) mentioned that $\beta$-carotene content in broccoli was ranged from $1.87-6.08 \mathrm{mg} / 100 \mathrm{~g}$ of dry weight.

Concerning to moringa, Nagib (2014) mentioned that, the Moringa oleifera leaves powder contained higher levels of vitamins $C$ and $\beta$-carotene being 24.8 and $19.72 \mathrm{mg} / 100 \mathrm{~g}$, respectively.

Regarding the lycopene content of the tomatoes, the obtained result show that tomato powder content $32.83 \mathrm{mg} / 100 \mathrm{~g}$ on dry weight basis. This result was concordant with the data obtained by N'Dri et al. (2010) and Baranska et al. (2006) they found that, lycopene content in tomato was ranged from 1.48 to $2.62 \mathrm{mg} / 100 \mathrm{~g}$ of fresh weight. Also, Borguini et al. (2013) found that, lycopene content in tomato was ranged from 37.43 to $40.80 \mathrm{mg} / 100 \mathrm{~g}$ of dry weight.

\section{Rheological characteristics of pizza dough:}

The farinogram and extensogram parameters of wheat flour and its blends with broccoli powder, tomato powder and moringa leaves powder are presented in Table (5). From the obtained data, it could be noticed that the water absorption of strong wheat flour was gradually increased as the level of substitution with broccoli powder, tomato powder and moringa leaves powder increased. The increased in water absorption of the wheat flour dough probably due to the higher fiber contents of broccoli powder, tomato powder and moringa leaves powder than wheat flour. These results are in agreement with Abd El-Moniem and Yassen (1993) reported that, addition of fiber sources to wheat flour caused an increased in water absorption of the produced dough. This may be due to higher water hydration capacity of fibers (Chen et al., 1988). Dough development time is the time from the addition of water to the time the dough reaches the point of greatest torque. During this phase of mixing, the water hydrates the flour components and the dough is developed. The farinograph data showed that, the addition of broccoli powder, tomato powder and moringa leaves powder increased dough development time; this may be due to the delay in the hydration and development of gluten caused by the presence of the above mentioned plant sources. 
Dough stability time is an important index for the dough strength based on the quantity and quality of dough gluten, so it could be observed that, the stability time of composite wheat flour dough with $1,2,3$ and $4 \%$ of broccoli powder was gradually increased from $11.0 \mathrm{~min}$. for control sample to $11.5,12.0,12.5$ and 13.0 min., respectively. While, the stability time of composite wheat flour dough with tomato powder and moringa leaves powder was gradually decreased with increasing the levels of substitution. The decrement in the stability time indicates weakness of dough strength. This weakness of the dough may be due to using both of tomato powder and moringa leaves powder which reduced the wheat gluten content (dilution effect) in the blends which make the dough more weak strength (Dachana et al., 2010).

Table 5: Effect of substituted wheat flour with different ratio of broccoli powder, tomato powder and moringa leaves powder on the rheological characteristics of pizza dough

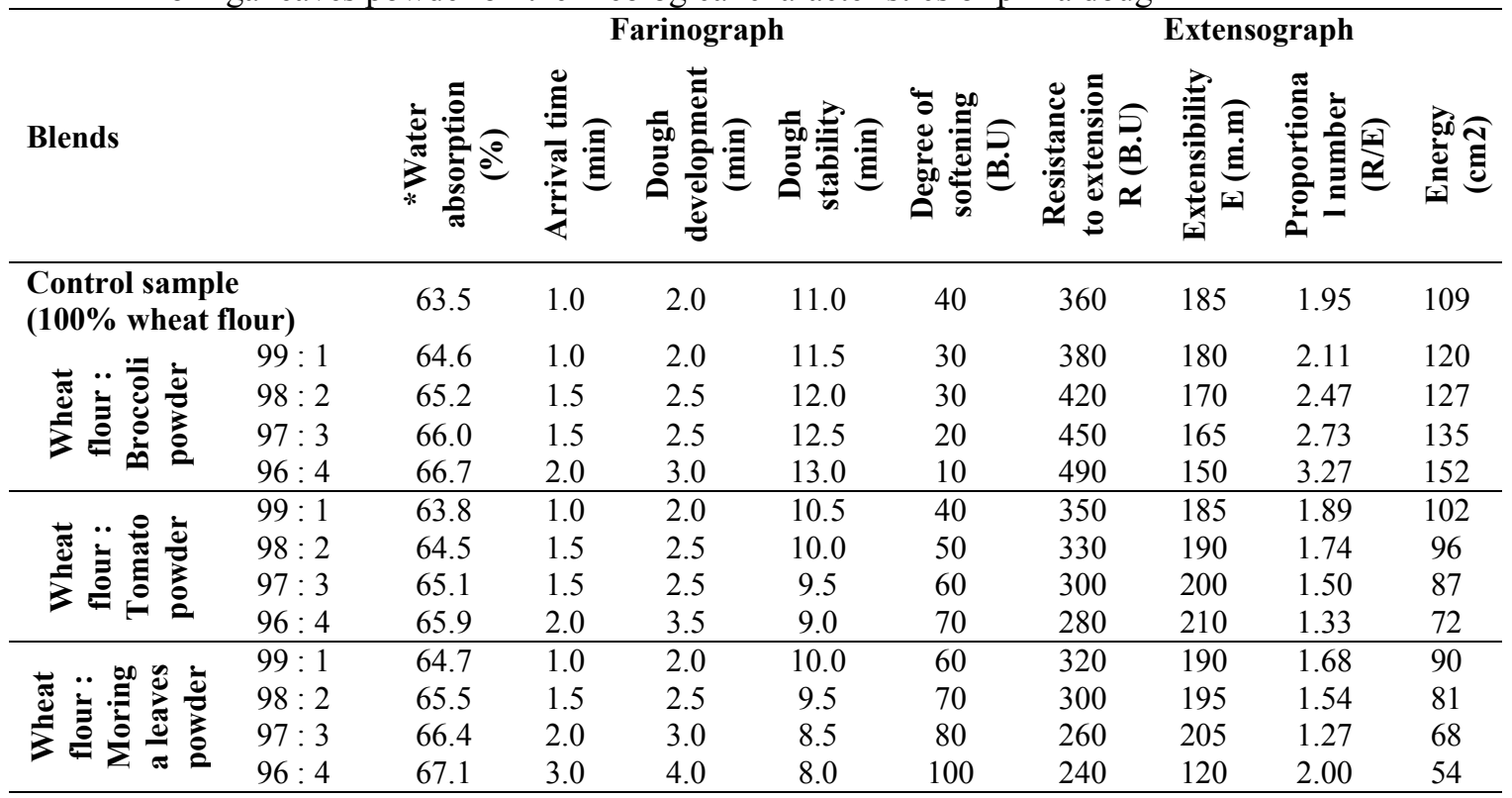

* Expressed on 14\% moisture basis.

B.U: Brabender Unit.

Concerning to the extensogram parameters, the results presented in the same table shows that, the resistance to extension of wheat flour dough was increased as a result to increase substitution levels with broccoli powder, it was 380, 420, 450 and 490 B.U for wheat flour dough replaced by 1, 2, 3 and $4 \%$ of broccoli powder, respectively, in compared with 360 B.U for wheat flour dough. In contrast, the resistance to extension of composite wheat flour dough with tomato powder and moringa leaves powder was gradually decreased with increasing the levels of substitution. The decrement in the resistance to extension indicates weakness of dough strength. This weakness of the dough may be due to using both of tomato powder and moringa leaves powder which reduced the wheat gluten content (dilution effect) in the blends which make the dough more weak strength. These results agree well with those reported by Abang et al. (2008) and Ktenioudaki et al. (2010). According to Bojňanska et al. (2013) who revealed that, the process of dough formation from the initial water addition to flour up to forming of compact dough with desired qualities (consistency, resistance to deformation, stability) goes through different phases during which fluidity, firmness and elasticity gradually change. Dough development time depends on amount and quality of gluten, flour granules and degree of milling and dough stability indicates the time interval during which dough maintains maximal consistency, and the high dough stability are considered of good quality from the point of view of further baking use (Skendi et al., 2009 and Bojňanska et al., 2013).

\section{Chemical composition of produced pizza:}

The results in Table (6) show the chemical composition of pizza produced by using $100 \%$ wheat flour ( $72 \%$ ext.) as a control sample and wheat flour composite with 1, 2, 3 and $4 \%$ of broccoli 
Curr. Sci. Int., 8(4): 852-873, 2019

Table 6: Chemical composition of produced pizza ( $\%$ on dry weight basis).

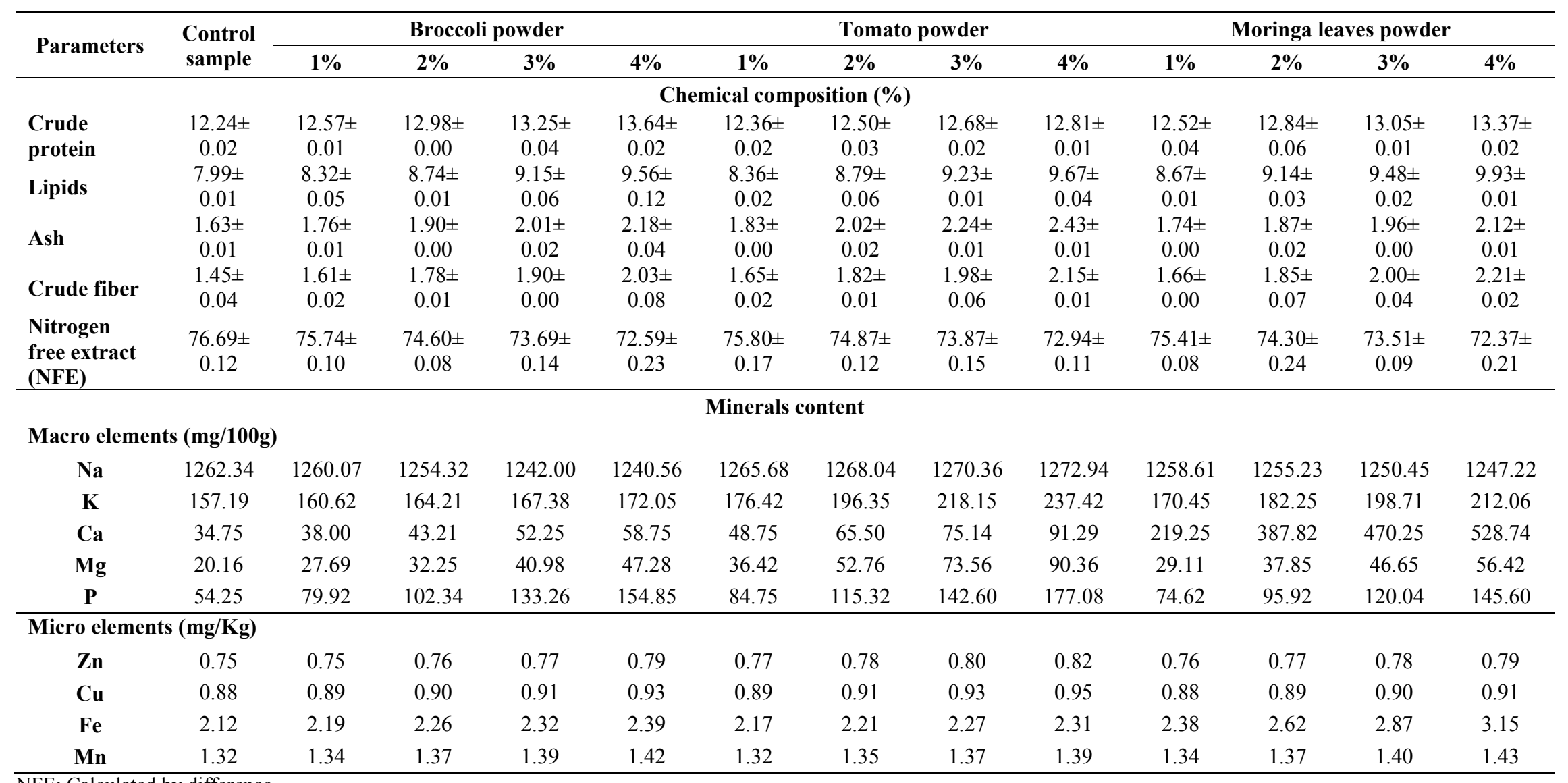

NFE: Calculated by difference. 
powder, tomato powder and moringa leaves powder. It could be noticed that, the control sample containing $12.24 \%$ crude protein, $7.99 \%$ lipids, $1.63 \%$ ash, $1.45 \%$ crude fiber and $76.69 \%$ nitrogen free extract (NFE).

Moreover, the replacement of wheat flour with 1, 2, 3 and 4\% of broccoli powder, tomato powder and moringa leaves powder caused gradually increase in both of crude protein, lipids, ash and crude fiber contents as the level of replacement increased, the increment in crude protein, lipids, ash and crude fiber contents of prepared pizza probably due to the relatively high content of these components in broccoli powder, tomato powder and moringa leaves powder than strong wheat flour as previously mentioned in Table (1). On the contrary, nitrogen free extract (NFE) were gradually decreased as the level of replacement increased. This is may be due to the low content of these components in broccoli powder, tomato powder and moringa leaves powder than strong wheat flour, as shown in Table (1).

Concerning to the minerals content of pizza the obtained results shown that, the minerals content of control pizza sample was 1262.34, 157.19, 34.75, 20.16, 54.25, 0.75, 0.88, 2.12 and 1.32 $\mathrm{mg} / 100 \mathrm{~g}$ for $\mathrm{Na}, \mathrm{K}, \mathrm{Ca}, \mathrm{Mg}, \mathrm{P}, \mathrm{Zn}, \mathrm{Cu}, \mathrm{Fe}$ and $\mathrm{Mn}$, respectively. Also, from the same Table, it could be observed that, substitution of wheat flour with 1, 2, 3 and 4\% of broccoli powder, tomato powder and moringa leaves powder caused gradually increase in all the under investigation minerals content accept for Sodium $(\mathrm{Na})$ as the level of broccoli powder, tomato powder and moringa leaves powder increased. The increment in minerals content of prepared pizza may be due to the higher content of these minerals in broccoli powder, tomato powder and moringa leaves powder in comparison with strong wheat flour (72\% ext.) as shown in Table (1). These results are in agreement with those obtained by Faryabidoust et al. (2013) and Nagib (2014).

\section{Determination of phenolic compounds in baked pizza:}

Phenolic compounds of pizza produced by using $100 \%$ wheat flour ( $72 \%$ ext.) as a control sample and wheat flour composite with 1, 2, 3 and 4\% of broccoli, tomato and moringa leaves powder were analyzed by High Performance Liquid Chromatography (HPLC), and the concentrations of all tested phenolic compounds were given in Table (7).

From the obtained results, it could be noticed that, the control sample containing the lower phenolic content than other pizza samples. Moreover, the replacement of wheat flour with 1, 2, 3 and $4 \%$ of broccoli, tomato and moringa leaves powder caused gradually increase in all phenolic compounds content, the increment in the phenolic compounds contents of prepared pizza probably due to the relatively high content of these components in broccoli, tomato and moringa leaves powder than strong wheat flour as previously mentioned in Table (2).

These results are in harmony, with those obtained by Sengey et al. (2012) they found that, the total phenolic content of bread samples fortified with moringa oleifera leaves powder increased. Also, Nagib (2014) found that, the total phenolic content of pizza samples fortified with moringa oleifera leaves powder increased.

Furthermore, Gawlik-Dziki et al. (2014) found that, supplementation of bread with broccoli sprouts significantly increased total phenolics content for $1-5 \%$ enriched bread than those obtained for control bread.

\section{Determination of flavonoids compounds in baked pizza:}

Flavonoids compounds of pizza produced by using $100 \%$ wheat flour (72\% ext.) as a control sample and wheat flour composite with 1, 2, 3 and 4\% of broccoli, tomato and moringa leaves powder were analyzed by High Performance Liquid Chromatography (HPLC), and the concentrations of all tested flavonoids compounds were given in Table (8).

From the obtained results, it could be noticed that, the control sample containing the lower flavonoids content than other pizza samples. Moreover, the replacement of wheat flour with 1, 2, 3 and $4 \%$ of broccoli, tomato and moringa leaves powder caused gradually increase in all flavonoids compounds content, the increment in the flavonoids compounds contents of prepared pizza probably due to the relatively high content of these components in broccoli, tomato and moringa leaves powder than strong wheat flour as previously mentioned in Table (3).

Finally, it can be said that broccoli, tomato and moringa leaves powder are also considered a rich source of polyphenols, flavonoids. These essential nutrients can help decrease the nutritional 
Table 7: Quantitative and qualitative analysis of phenolic compounds in produced pizza by HPLC (mg/100g)

\begin{tabular}{|c|c|c|c|c|c|c|c|c|c|c|c|c|c|}
\hline \multirow{2}{*}{$\begin{array}{c}\text { Phenolic compounds } \\
\text { (mg/100g) }\end{array}$} & \multirow{2}{*}{$\begin{array}{l}\text { Control } \\
\text { sample }\end{array}$} & \multicolumn{4}{|c|}{ Broccoli powder } & \multicolumn{4}{|c|}{ Tomato powder } & \multicolumn{4}{|c|}{ Moringa leaves powder } \\
\hline & & $1 \%$ & $2 \%$ & $3 \%$ & $4 \%$ & $1 \%$ & $2 \%$ & $3 \%$ & $4 \%$ & $1 \%$ & $2 \%$ & $3 \%$ & $4 \%$ \\
\hline Pyrogallol & 0.335 & 2.413 & 3.721 & 6.811 & 9.971 & 1.367 & 2.652 & 4.497 & 5.784 & 1.107 & 2.365 & 3.298 & 5.460 \\
\hline Benzoic acid & 0.005 & 0.182 & 0.433 & 0.624 & 0.853 & 0.164 & 0.318 & 0.456 & 0.607 & 0.032 & 0.046 & 0.059 & 0.071 \\
\hline 4-amino-benzoic acid & 0.007 & 0.029 & 0.061 & 0.097 & 0.112 & 0.033 & 0.052 & 0.094 & 0.164 & 0.011 & 0.025 & 0.037 & 0.054 \\
\hline 3,4,5-methoxy-cinnamic & 0.002 & 0.014 & 0.027 & 0.041 & 0.056 & 0.017 & 0.032 & 0.045 & 0.067 & 0.005 & 0.009 & 0.016 & 0.029 \\
\hline Protocatchuic acid & 0.060 & 0.071 & 0.132 & 0.198 & 0.288 & 0.061 & 0.113 & 0.193 & 0.281 & 0.521 & 0.985 & 1.754 & 2.138 \\
\hline Catechol & 0.172 & 0.235 & 0.352 & 0.511 & 0.782 & 0.199 & 0.278 & 0.319 & 0.402 & 0.627 & 1.637 & 3.022 & 3.768 \\
\hline Chlorgenic acid & 0.072 & 0.118 & 0.183 & 0.372 & 0.483 & 0.481 & 0.923 & 1.356 & 1.872 & 0.432 & 0.835 & 1.192 & 1.824 \\
\hline Caffiec acid & 0.010 & 0.025 & 0.031 & 0.039 & 0.052 & 0.131 & 0.272 & 0.403 & 0.582 & 2.035 & 4.974 & 7.822 & 10.330 \\
\hline Caffeine & 0.003 & 0.092 & 0.138 & 0.272 & 0.433 & 0.181 & 0.208 & 0.394 & 0.561 & 0.117 & 0.268 & 0.591 & 0.772 \\
\hline Vanillic acid & 0.081 & 0.095 & 0.232 & 0.391 & 0.522 & 0.011 & 0.036 & 0.052 & 0.118 & 0.098 & 0.210 & 0.384 & 0.522 \\
\hline E-vanillic acid & 0.017 & 0.991 & 1.925 & 2.508 & 3.834 & 0.098 & 0.182 & 0.384 & 0.566 & 0.070 & 0.116 & 0.209 & 0.321 \\
\hline Alpha-Coumaric & 0.001 & 0.077 & 0.131 & 0.210 & 0.283 & 0.006 & 0.017 & 0.026 & 0.030 & 0.004 & 0.010 & 0.019 & 0.027 \\
\hline Salycilic acid & 0.027 & 0.068 & 0.108 & 0.149 & 0.190 & 0.828 & 1.544 & 2.417 & 3.394 & 0.069 & 0.124 & 0.185 & 0.311 \\
\hline Gallic acid & 0.008 & 0.038 & 0.075 & 0.098 & 0.142 & 0.055 & 0.071 & 0.102 & 0.133 & 0.083 & 0.119 & 0.184 & 0.328 \\
\hline Ellagic acid & 0.007 & 0.132 & 0.286 & 0.484 & 0.552 & 2.956 & 6.933 & 10.410 & 13.820 & 0.388 & 0.519 & 0.654 & 0.786 \\
\hline P-OH-benzoic acid & ND & 0.039 & 0.082 & 0.167 & 0.206 & 0.021 & 0.066 & 0.095 & 0.148 & 0.030 & 0.052 & 0.087 & 0.135 \\
\hline Catechin & ND & 0.062 & 0.097 & 0.183 & 0.254 & 0.018 & 0.033 & 0.056 & 0.087 & 1.782 & 3.362 & 4.921 & 6.714 \\
\hline Epicatechin & ND & 0.027 & 0.073 & 0.112 & 0.158 & 0.053 & 0.074 & 0.105 & 0.147 & 0.016 & 0.055 & 0.092 & 0.132 \\
\hline Ferulic acid & 0.008 & 0.013 & 0.028 & 0.048 & 0.061 & 0.052 & 0.115 & 0.185 & 0.233 & 0.019 & 0.036 & 0.041 & 0.044 \\
\hline Iso-Ferulic & 0.021 & 0.143 & 0.298 & 0.333 & 0.402 & 0.095 & 0.194 & 0.303 & 0.396 & 0.022 & 0.049 & 0.087 & 0.126 \\
\hline Resveratol & 0.013 & 0.023 & 0.035 & 0.042 & 0.052 & 0.013 & 0.015 & 0.019 & 0.021 & 0.019 & 0.024 & 0.032 & 0.038 \\
\hline Coumarin & 0.001 & 0.022 & 0.038 & 0.069 & 0.082 & 0.008 & 0.019 & 0.027 & 0.035 & 0.004 & 0.012 & 0.018 & 0.023 \\
\hline P-coumaric acid & 0.030 & 0.118 & 0.340 & 0.570 & 0.812 & 0.036 & 0.075 & 0.156 & 0.199 & 0.044 & 0.080 & 0.109 & 0.146 \\
\hline Cinammic acid & 0.002 & 0.015 & 0.032 & 0.054 & 0.076 & 0.006 & 0.014 & 0.021 & 0.030 & 0.004 & 0.009 & 0.012 & 0.015 \\
\hline
\end{tabular}


Curr. Sci. Int., 8(4): 852-873, 2019

Table 8: Quantitative and qualitative analysis of flavonoids compounds in produced pizza by HPLC (mg/100g)

\begin{tabular}{|c|c|c|c|c|c|c|c|c|c|c|c|c|c|}
\hline \multirow{2}{*}{$\begin{array}{l}\text { Flavonoids } \\
\text { compounds } \\
(\mathbf{m g} / \mathbf{1 0 0 g})\end{array}$} & \multirow{2}{*}{$\begin{array}{l}\text { Control } \\
\text { sample }\end{array}$} & \multicolumn{4}{|c|}{ Broccoli powder } & \multicolumn{4}{|c|}{ Tomato powder } & \multicolumn{4}{|c|}{ Moringa leaves powder } \\
\hline & & $1 \%$ & $2 \%$ & $3 \%$ & $4 \%$ & $1 \%$ & $2 \%$ & $3 \%$ & $4 \%$ & $1 \%$ & $2 \%$ & $3 \%$ & $4 \%$ \\
\hline Rosmarinic & 0.005 & 0.372 & 0.774 & 1.161 & 1.629 & 0.045 & 0.083 & 0.109 & 0.210 & 0.032 & 0.039 & 0.095 & 0.167 \\
\hline Rutin & 0.003 & 0.011 & 0.037 & 0.053 & 0.071 & 0.074 & 0.177 & 0.288 & 0.404 & 0.133 & 0.382 & 0.583 & 0.757 \\
\hline Quercitin & 0.002 & 0.008 & 0.018 & 0.037 & 0.052 & 0.382 & 0.752 & 0.904 & 1.385 & 1.100 & 1.972 & 3.024 & 4.882 \\
\hline Kaempferol & ND & 0.001 & 0.002 & 0.008 & 0.010 & 0.011 & 0.019 & 0.035 & 0.049 & 0.006 & 0.011 & 0.021 & 0.030 \\
\hline Apigenin & ND & 0.004 & 0.007 & 0.012 & 0.018 & 0.002 & 0.005 & 0.010 & 0.015 & 0.004 & 0.008 & 0.011 & 0.019 \\
\hline Hesperetin & 0.009 & 0.018 & 0.033 & 0.133 & 0.202 & 0.016 & 0.072 & 0.152 & 0.346 & 0.015 & 0.043 & 0.091 & 0.128 \\
\hline Hesperidin & 0.019 & 0.097 & 0.522 & 1.883 & 2.803 & 0.165 & 0.896 & 1.344 & 1.843 & 0.141 & 0.275 & 0.453 & 0.622 \\
\hline Luteolin & 0.071 & 0.340 & 0.758 & 1.697 & 2.719 & 0.132 & 0.445 & 0.691 & 0.793 & 0.239 & 0.933 & 0.982 & 1.172 \\
\hline Naringin & 0.005 & 0.105 & 0.574 & 1.246 & 1.388 & 0.082 & 0.382 & 0.524 & 0.533 & 0.054 & 0.086 & 0.124 & 0.208 \\
\hline Naringenin & 0.001 & 0.039 & 0.077 & 0.102 & 0.197 & 0.092 & 0.183 & 0.242 & 0.377 & 0.009 & 0.014 & 0.043 & 0.082 \\
\hline
\end{tabular}


deficit and combat many chronic diseases. These results are in agreement with those obtained by Bhandari and Kwak (2014) and Marti et al. (2016).

\section{Determination of vitamin $C$, beta-carotene and lycopene in baked pizza:}

Vitamin C, beta-carotene and lycopene compounds of pizza produced by using $100 \%$ wheat flour $(72 \%$ ext.) as a control sample and wheat flour composite with $1,2,3$ and $4 \%$ of broccoli, tomato and moringa leaves powder were determined and the obtained results are presented in Table (9).

From the obtained results, it could be noticed that, the control sample containing the lower vitamin $\mathrm{C}$, beta-carotene and lycopene content than other pizza samples. Moreover, the replacement of wheat flour with 1,2,3 and 4\% of broccoli, tomato and moringa leaves powder caused gradually increase in vitamin $\mathrm{C}$, beta-carotene and lycopene content, the increment in the vitamin $\mathrm{C}$, betacarotene and lycopene contents of prepared pizza probably due to the relatively high content of these components in broccoli, tomato and moringa leaves powder than strong wheat flour as previously mentioned in Table (4).

Table 9: Vitamin C, $\beta$-Carotene and lycopene content of produced pizza by HPLC (mg/100g)

\begin{tabular}{lcccc}
\hline & Substitution level (\%) & Vitamin C & $\begin{array}{c}\text { Compounds (mg/100g) } \\
\boldsymbol{\beta} \text {-Carotene }\end{array}$ & \begin{tabular}{c} 
Lycopene \\
\hline Control sample
\end{tabular} \\
& 1 & 0.066 & 0.010 & ND \\
Broccoli powder & 2 & 0.624 & 0.013 & ND \\
& 3 & 1.394 & 0.019 & ND \\
& 4 & 2.171 & 0.038 & ND \\
Tomato powder & 1 & 2.829 & 0.042 & 0.019 \\
& 2 & 0.133 & 0.011 & 0.042 \\
& 3 & 0.275 & 0.031 & 0.072 \\
Moringa leaves & 4 & 0.411 & 0.047 & ND \\
powder & 1 & 0.582 & 0.061 & ND \\
& 2 & 0.172 & 0.139 & ND \\
\hline
\end{tabular}

ND: Not determined.

These results are in agreement with Fuglie (1999) mentioned that, Moringa oleifera leaves contain seven times the vitamin $C$ in oranges, four times the calcium in milk, four times the $\beta$ carotene in carrots, twice the protein in milk and three times the potassium in bananas. In the same trend, Mona-Halaby et al. (2013) and Nagib (2014) they found that, both of vitamin C and betacarotene contents of pizza fortified with different levels of Moringa oleifera leaves powder increased as the levels of fortification increased.

\section{Texture profile of produced pizza:}

The textural characteristics of produced pizza were investigated by conducting a texture profile analysis in terms of Hardness (N), Cohesiveness, Gumminess (N), Chewiness (mj), Adhesiveness $(\mathrm{mj})$ and Springiness $(\mathrm{mm})$ of produced pizza.

The results presented in Table (10) show the mechanical properties of pizza produced by using $100 \%$ wheat flour ( $72 \%$ ext.) as a control sample and wheat flour composite with 1, 2, 3 and $4 \%$ of broccoli powder, tomato powder and moringa leaves powder. The hardness (firmness) must be explained by the different chemical interactions between oil, protein starch and fiber that affect its retrogradation, the interactions between the swollen starch granules, fiber and the protein network actively contribute to crumb firming. The lowest values in hardness were found in control pizza. While, pizza samples which contained the different levels of broccoli powder, tomato powder and moringa leaves powder led to increase the hardness than that of the control pizza sample. An increase in chewiness and gumminess values with increasing the replacement levels with broccoli powder, tomato powder and moringa leaves powder. Chewiness is one of the texture parameters easily correlated with sensory evaluation through trained panels (Esteller et al., 2004). 
Both, cohesiveness, gumminess and chewiness are parameters dependent on firmness. Therefore, their values followed a similar trend than that of firmness. Cohesiveness quantifies the internal resistance of food structure. As happened with firmness, pizza cohesiveness depended on the replacement with different levels of broccoli powder, tomato powder and moringa leaves powder. A similar result was also obtained in other baked goods (Esteller et al., 2004). Regarding springiness change the obtained results show that, the values of springiness was decreased with increasing the replacement levels with broccoli powder, tomato powder and moringa leaves powder. A subjective evaluation of springiness is normally made by consumers and consists of slightly pressing the piece of food, by hand or with the mouth, and verifying how easily it returns to the original size.

Table 10: Effect of substituted wheat flour with different ratio of broccoli powder, tomato powder and moringa leaves powder on the texture measurement (mechanical properties) of pizza at zero time.

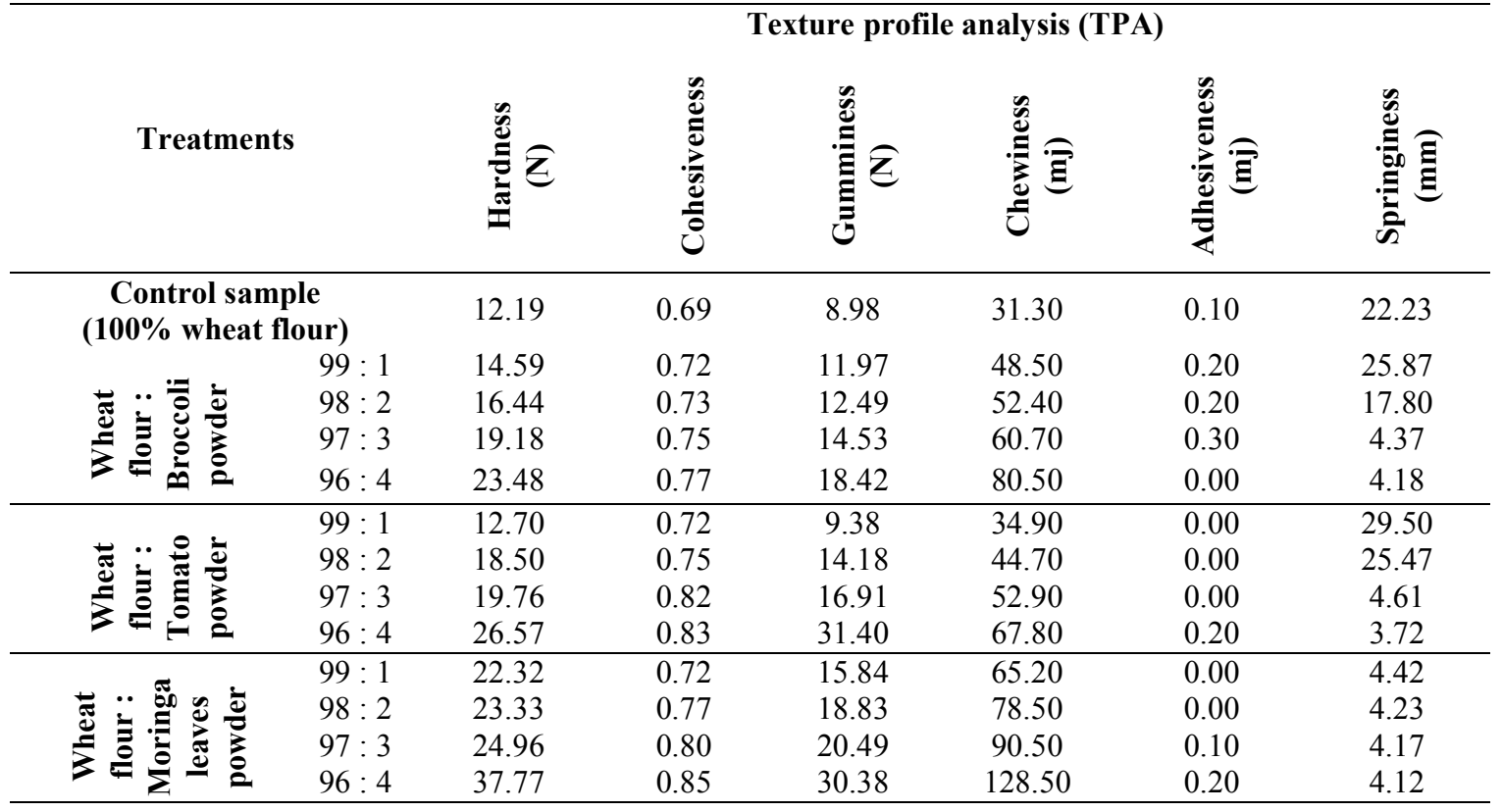

\section{Sensory evaluation of fresh pizza:}

The organoleptic properties of pizza produced by using $100 \%$ wheat flour ( $72 \%$ ext.) as control sample and pizza samples which prepared by partial replacement of wheat flour by 1,2, 3 and $4 \%$ of broccoli powder, tomato powder and moringa leaves powder were evaluated to select the best substitution level for produce high quality pizza. The pizza samples were evaluated by ten panelists for their external and internal properties as shown in Table (11). The results in this Table showed that, there were no significant differences in crust color of produced pizza between the control sample and $1,2 \%$ level of substitution with broccoli powder and tomato powder. On the other hand, significant differences in crust color between the control sample and $2 \%$ substitution level with moringa leaves powder were recorded. Concerning the odor, no significant difference was recorded between control sample and pizza samples which substituted with 1 and $2 \%$ broccoli powder and tomato powder, but there were significant differences between control sample and pizza sample contained $2 \%$ of moringa leaves powder. For taste, the obtained results indicated that there were significant differences between control sample and pizza samples which substituted with 3 and $4 \%$ broccoli powder and moringa leaves powder. In addition, the obtained results indicated that, there were no significant differences between control pizza sample and pizza samples contained 1, 2\% level of substitution for texture. On the other hand, there were no significant differences between control sample and pizza samples which substituted with 1 and $2 \%$ of broccoli powder and tomato powder for general appearance, but there was significant difference with pizza sample which substituted with $2 \%$ moringa leaves powder.

The total scores values were a reflection of all the tested quality attributes and acceptability of the studied pizza samples. These values were calculated from 100 as a sum of received sensory score. 
The results demonstrated that, the mean total score values of control bread sample which produced by using $100 \%$ wheat flour ( $72 \%$ extraction rate) was higher than those of other samples and decreased gradually with non-significant differences compared with control sample until $3 \%$ substitution level with broccoli powder and tomato powder, but there was significant difference with pizza sample which substituted with moringa leaves powder. These results are in agreement with those obtained by Abraham et al. (2013) and Nagib (2014) they recorded that, the acceptability of all pizza samples decreased with increasing level of moringa leaves powder supplementation.

Table 11: Sensory evaluation of fresh pizza prepared by partially substituted of wheat flour with different ratio of broccoli powder, tomato powder and moringa leaves powder

\begin{tabular}{|c|c|c|c|c|c|c|c|}
\hline \multicolumn{2}{|c|}{ Blends } & \multirow{2}{*}{ 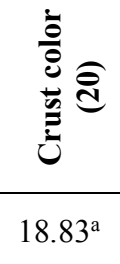 } & \multirow{2}{*}{ 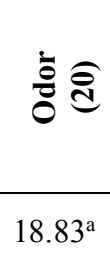 } & \multirow{2}{*}{ 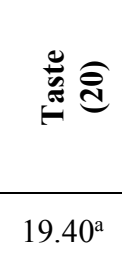 } & \multirow{2}{*}{ 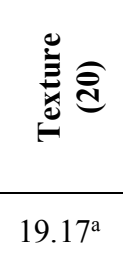 } & \multirow{2}{*}{ 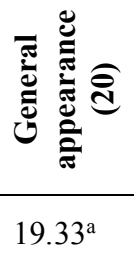 } & \multirow{2}{*}{ 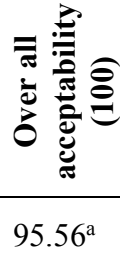 } \\
\hline $\begin{array}{l}\text { Control } \\
(\mathbf{1 0 0 \%} \text { wh }\end{array}$ & $\begin{array}{l}\text { iple } \\
\text { flour) }\end{array}$ & & & & & & \\
\hline \multirow{4}{*}{ 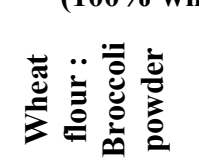 } & $99: 1$ & $18.17^{\mathrm{a}}$ & $18.17^{\mathrm{a}}$ & $18.80^{\mathrm{a}}$ & $18.17^{\mathrm{a}}$ & $18.33^{\mathrm{a}}$ & $91.64^{\mathrm{a}}$ \\
\hline & $98: 2$ & $17.67^{\mathrm{ab}}$ & $17.33^{\mathrm{ab}}$ & $18.00^{\mathrm{ab}}$ & $17.50^{\mathrm{ab}}$ & $18.17^{\mathrm{a}}$ & $88.67^{\mathrm{ab}}$ \\
\hline & $97: 3$ & $17.00^{\mathrm{b}}$ & $16.67^{\mathrm{b}}$ & $16.40^{\mathrm{b}}$ & $17.17^{\mathrm{b}}$ & $17.50^{\mathrm{b}}$ & $84.74^{\mathrm{ab}}$ \\
\hline & $96: 4$ & $16.50^{\mathrm{b}}$ & $16.00^{\mathrm{bc}}$ & $15.60^{\mathrm{bc}}$ & $16.33^{\mathrm{bc}}$ & $16.83^{b c}$ & $81.26^{\mathrm{b}}$ \\
\hline \multirow{4}{*}{ 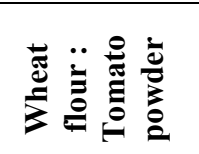 } & $99: 1$ & $18.50^{\mathrm{a}}$ & $18.83^{\mathrm{a}}$ & $18.80^{\mathrm{a}}$ & $19.17^{\mathrm{a}}$ & $19.33^{\mathrm{a}}$ & $94.63^{\mathrm{a}}$ \\
\hline & $98: 2$ & $18.33^{\mathrm{a}}$ & $18.50^{\mathrm{a}}$ & $18.60^{\mathrm{a}}$ & $18.80^{\mathrm{a}}$ & $18.67^{\mathrm{a}}$ & $92.90^{\mathrm{a}}$ \\
\hline & $97: 3$ & $17.67^{\mathrm{ab}}$ & $18.50^{\mathrm{a}}$ & $18.60^{\mathrm{a}}$ & $18.33^{\mathrm{a}}$ & $18.00^{\mathrm{ab}}$ & $91.10^{\mathrm{a}}$ \\
\hline & $96: 4$ & $17.17^{\mathrm{b}}$ & $18.33^{\mathrm{a}}$ & $18.20^{\mathrm{ab}}$ & $17.00^{\mathrm{b}}$ & $17.50^{\mathrm{b}}$ & $88.20^{\mathrm{ab}}$ \\
\hline \multirow{4}{*}{ 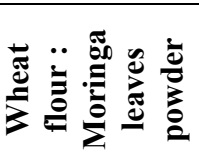 } & $99: 1$ & $17.83^{\mathrm{ab}}$ & $17.17^{\mathrm{ab}}$ & $18.40^{\mathrm{a}}$ & $18.17^{\mathrm{a}}$ & $18.17^{\mathrm{a}}$ & $89.74^{\mathrm{ab}}$ \\
\hline & $98: 2$ & $17.17^{\mathrm{b}}$ & $16.83^{\mathrm{b}}$ & $18.00^{\mathrm{ab}}$ & $17.67^{\mathrm{ab}}$ & $17.33^{\mathrm{b}}$ & $87.00^{\mathrm{ab}}$ \\
\hline & $97: 3$ & $16.00^{\mathrm{bc}}$ & $16.50^{\mathrm{bc}}$ & $16.00^{\mathrm{bc}}$ & $17.17^{\mathrm{b}}$ & $16.17^{\mathrm{bc}}$ & $81.84^{\mathrm{b}}$ \\
\hline & $96: 4$ & $14.00^{\mathrm{c}}$ & $15.83^{\mathrm{c}}$ & $14.00^{c}$ & $13.67^{\mathrm{c}}$ & $13.00^{\mathrm{d}}$ & $70.50^{c}$ \\
\hline
\end{tabular}

* Means followed by different letters in the same column are significantly different by Duncan's multiple test $(\mathrm{p}<0.05)$.

\section{References}

A.A.C.C., 2000. American Association of Cereal Chemists. Approved Methods of the A.A.C.C. Published by the American Association of Cereal Chemists, $10^{\text {th }}$ Ed., St. Paul, MN. USA.

A.O.A.C., 2000. Official Methods of Analysis, $17^{\text {th }}$ Ed., Association of Official Analytical Chemists International. Gaithersburg, Maryland, USA.

Abang, Z., N. Chin, R. Abdul, R. Rahman and R. Karim, 2008. Rheological characterisation of gluten from extensibility measurement. J. Food Engineering, 86 (4): 549-556.

Abd El-Fatah, N., A.A. Metwalli and O.S. Ragab, 2013. Preparation and Evaluation of Instant Noodles Supplemented with Natural Sources of High Lysine Content. Egypt. J. Agric. Res., 91(3): 1065-1078.

Abd El-Moniem, G.M. and A.A. Yaseen, 1993. High dietary fibre cookies from several sources of bran or husk. Egypt J. Food Sci., 21(2): 157-170.

Abraham, I., O. Joseph, I. Dick and A. Gernah, 2013. Effect of Moringa oleifera Leaf Powder Supplementation on Some Quality Characteristics of Wheat Bread Food and Nutrition Sciences, 4: $270-275$.

Abushita, A.A., H.G. Daood and P.A. Biacs, 2000. Change in carotenoids and antioxidant vitamins in tomato as a function of varietal and technological factors. Journal of Agricultural and Food Chemistry 48: 2075-2081.

American Cancer Society, 1984. Nutrition and cancer: caution and prevention. An American Cancer Society Special Report. CA: A Cancer Journal for Clinicians, 34: 5-10. 
Ashoush, Y.A.M., A.M.F. Ali, M.M. Abozid and M.S.M. Salama, 2017. Comparative study between celery leaves and broccoli flowers for their chemical composition and amino acids as well as phenolic and flavonoid compounds. Menoufia J. Agric. Biotechnology, 2 (2): 1-13.

Astm, S., 1975. Annual book of American society of testing materials standard water. Part 31 Dsis72-Philadelphia, PA.

Awad, R., A.A. Farahat and W. M. Salama 2012. Production and in vivo Nutritional Evaluation of Functional Soft Cheese Supplemented with Broccoli. World J. Dairy and Food Sci., 7 (2): 150159.

Balan, D., F. Israel-Roming, G. Luta and E. Gherghina, 2016. Changes in the nutrients content of some green vegetables during storage and thermal processing. Romanian Biotechnological Letters, 21 (5): 11857-11865.

Baranska, M., W. Schutze and H. Schulz, 2006. Determination of lycopene and beta-carotene content in tomato fruits and related products. Comparasion of FT-Ramman, ATR-IR and NIR spectroscopy. Anal Chem., 78 (24): 8456-8461.

Bashir, N., M.A. Bhat, B.N. Dar and M.A. Shah, 2014. Effect of different drying methods on the quality of tomatoes. Advances in Food Sciences, 36 (2): 65-69.

Beecher, G.R. 1998. Nutrient content of tomatoes and tomato products. Proceedings of the Society of Experimental Biology and Medicine, 218: 98-100.

Beveridge, T., E. Loubert and J. E. Harrison, 2000. Simple measurement of phenolic esters in plant cell walls. Food Research International, 33: 775-783.

Bhandari, S.R. and J. Kwak, 2014. Seasonal variation in phytochemicals and antioxidant activities in different tissues of various broccoli cultivars. African Journal of Biotechnology, 13 (4): $604-$ 615.

Biase, L. D. and A. Zacchetti, 1996. Caccia grossa al cliente. Panorama. 28: 86-90.

Block, G., C. Jensen, M. Dietrich, E.P. Norkus, M. Hudes, and L. Packer, 2004. Plasma C-reactive protein concentrations in active and passive smokers: Influence of antioxidant suplementation. Journal of the American College of Nutrition, 23(2): 141-147.

Block, G., B. Patterson, and A. Subar, 1992. Fruit, vegetables, and cancer prevention: A review of the epidemiological evidence. Nutrition and Cancer, 18: 1-29.

Bojňanská, T., M. Tokár, K. Mocko, H. Balková, H. Frančáková, E. Ivanišová, and T. Roháčik, 2013. Evaluation of new varieties of summer wheat Triticum Aestivum L. considering selected parameters of technological quality. J. Microbiology, Biotechnology and Food Sciences, 12811292.

Borguini, R.G., D.H. Markowicz-Bastos, J.M. Moita-Neto, F.S. Capasso, and E.A. da Silva Torres, 2013 . Antioxidant potential of tomatoes cultivated in organic and conventional systems. Beazilian Archives of Biology and technology, 56 (4): 521-529.

Borowski, J., A. Szajdek and E.J. Borowska, 2008. Content of selected bioactive components and antioxidant properties of broccoli (Brassica oleracea L.). Eur. Food Res. Technol., 246: 459465.

Canaud, B., J. Cristol, M. Morena, H. Leray-Moragues, J. Bosc, and F. Vaussenat, 1999. Imbalance of oxidants and antioxidants in haemodialysis patients. Blood Purif., 17(2-3):99-106.

Chapman, H.D. and P.F. Pratt, 1978. Methods of analysis for soils, plants and waters, Univ. California, Div. Agric. Sci., Priced publication, 4034.

Chen, H., G.L. Rubenthaler, and E.C. Schamus, 1988. Effect of apple fiber and cellulose on the physical properties of wheat flour. J. Food Sci., 53 (1): 304-306.

Dachana, K.B., A.J. Rajiv, D. Indrani, and J. Prakash, 2010. Effect of dried moringa (Moringa oleifera L.) leaves on rheological, microstructural, nutritional, textural and organoleptic characteristics of cookies. Journal of Food Quality 33: 660-677.

Dalia-Kotb, A., M.R. Shahein, M.A. Abd El-Whab and M.M.K. Metwally, 2017. Determination of polyphenolic compounds and antioxidant activity of olive leave, moringa leave and marigold petals extracts. World Journal of Dairy and Food Sciences 12 (2): 102-107.

Davey, M.W., M. van Montagu, D. Inze, M. Sanmartin, A. Kanellis and N. Smirnoff, 2000. Plant Lascorbic acid: Chemistry, function, metabolism, bioavailability and effects of processing. Journal of the Science of Food and Agriculture, 80: 825-860. 
Davies, J.N. and G.E. Hobson, 1981. The constituents of tomato fruit-The influence of environment, nutrition, and genotype. CRC Critical Reviews in Food Science and Nutrition 15: 205-280.

De Sa, M.C. and D.B. Rodriguez-Amaya, 2004. Optimization of HPLC quantification of carotenoids in cooked green vegetables-Comparison of analytical and calculated data. Journal of Food Composition and Analysis, 17: 37-51.

Elbadrawy, E. and A. Sello, 2016. Evaluation of nutritional value and antioxidant activity of tomato peel extracts. Arabian Journal of Chemistry, 9: 1010-1018.

Esteller, M.S., R.L. Amaral and S.C. Lannes, 2004. Effect of sugar and fat replacers on the texture of baked goods. J. Texture Studies, 35:383-393.

Fahey, J. D., P. Kostova and P.Talalay, 2004. The "Prochaska" microtiter plate bioassay for inducers of NQO1. Chapter 14 in Methods in Enzymology, 382: 243-258.

Fahey, J.W., A.T. Zalcmann, and P. Talalay, 2001. The chemical diversity and distribution of glucosinolates and isothiocyanates among plants. Phytochemistry, 56: 5-51.

Faizi, S., B.S. siddiqui, R. Saleem, S. Siddiqui, K. Aftab, and A.H. Gilani, 1995. Fully acetylated carbamate and hypotensive thiocarbamate glycosides from Moringa oleifera. Phytochemistry, 38:957-963.

Farooq, F., M. Rai, A. Tiwari, A. Khan and S. Farooq, 2012. Medicinal properties of Moringa oleifera: An overview of promising healer. J. of Medicinal Plants Research, 6 (27): 4368-4374.

Faryabidoust, B., L. Asadpour, and S. Nassabian, 2013. The study of the effect of multi-enzyme supplementation and different levels of tomato pomace on the performance and carcass characteristics of broiler chicks. Global Veterinaria, 10 (3): 337-342.

Figueiredo, S.M., N.S. Binda, J.A. Nogueira-Machado, S.A. Vieira-Filho, and R.B. Caligiorne, 2015. The antioxidant properties of organosulfur compounds (Sulforaphane). Recent. Pat. Endocr. Metab. Immune. Drug Discov., 9: 24-39.

Franceschi, S., E. Bidoli, C. La Vecchia, R. Talamini, B. Davanzo and E. Negri, 1994 . Tomatoes and risk of digestive-tract cancers. International Journal of Epidemiology, 59: 181-184.

Frankel, E.N. 1995. Natural and biological antioxidant systems. Their mechanisms of action, applications and implications. Lipid Technol., 7: 77-80.

Fuglie, L.J. 1999. The Miracle Tree: Moringa oleifera: Natural Nutrition for the Tropics. Revised edition. Church World Service, Dakar. p. 68.

Galan, M.V., A.A. Kishanand, and A.L. Silverman, 2004. Oral broccoli sprouts for the treatment of Helicobacter pylori infection: a preliminary report. Dis. Dig. Sci. 49:1088-1090.

Gawlik-Dziki, U., M. Uwieca, D. Dziki, A. Swczyk, U. Botek, R. Róhy, K. Kaszuba, D. Ryszawy, and J. Czyh, 2014 . Anticancer and antioxidant activity of bread enriched with broccoli sprouts. BioMed Research International, 1:1-14.

Gerster, H. 1997. The potential role of lycopene in human health. Journal of American College of Nutrition, 16: 109-126.

Giovanelli, G., V. Lavelli, C. Peri, and S. Nobili, 1999. Variation in antioxidant compounds of tomato during vine and post-harvest ripening. Journal of the Science of Food and Agriculture, 79: 1583-1588.

Giovannucci, E. 1999. Tomatoes, tomato-based products, lycopene and cancer-Review of the epidemiologic literature. Journal of the National Cancer Institute 91 (4): 317-331.

Gliszczynska-Swiglo, A., E. Ciska, K. Pawlak-Lemanska, J. Chmielewski, T. Borkowski, and B. Tyrakowska, 2006 . Changes in the content of health-promoting compounds and antioxidant activity of broccoli after domestic processing. Food Addit. Contam., 23: 1088-1098.

Goupy, P., M. Hugues, P. Biovin, and M.J. Amiot, 1999. Antioxidant composition and activity of barley (Hordeum vuigare) and malt extracts and of isolated phenolic compounds. J. Sci. Food Agric. 79: 1625-1634.

Gross, J. 1987. Pigments in fruits. Academic Press: London.

Gundgaard, J., J.N. Nielsen, J. Olsen, and J. Sorensen, 2003. Increased intake of fruit and vegetables: estimation of impact in terms of life expectancy and healthcare costs. Public Health Nutr., 6: 25-30.

Hanldelman, G.J. 1996. Carotenoids as scavengers of active oxygen species, in Handbook of Antioxidants, Ed by Cadenas, E. and Packer, L., Marcel Dekker, New York, pp 259-315. 
Heinonen, I.M., J.L. Pekka and A.I. Hopia, 1998. Antioxidant activity of berry and fruit wines and liquors. J. Agric. Food Chem., 46: 25-31.

Herrmann, K. 1989. Occurrence and content of hydroxycinnamic acid and hydroxybenzoic acid compounds in foods. Critical Reviews of Food Science and Nutrition, 28: 315-347.

Hounsome, N., B. Hounsome, D. Tomos and G. Edwards-Jones, 2009. Changes in antioxidant compounds in white cabbage during winter storage. Postharvest Biol. Technol. 52: 173-179.

Kahlon, T.S., M.H. Chapman and G.E. Smith, 2005. In vitro binding of bile acids by spinach, kale, brussels sprouts, broccoli, mustard greens, green bell pepper, cabbage and collards. Food Chem., 100: 1531-1536.

Kaur, C., K. Kumar, D. Anil, and H.C. Kapoor, 2007. Variations in antioxidant activity in beoccoli (Brassica oleracea L.) cultivars. Journal of Food Biochemistry 31: 621-638.

Khalil, I.A. and F.R. Varananis, 1996. Carotiniod extraction and analysis by reversed phase HPLC system. Sarhad J. Agric., 105 (67): 15-21.

Kirkegaard, J.A. and M. Sarwar, 1998. Biofumigation potential of brassicas. Plant Soil 201: 71-89.

Koh, E., K.M.S. Wimalasiri, A.W. Chassy and A.E. Mitchell, 2009. Content of ascorbic acid, quercetin, kaempferol and total phenolics in commercial broccoli. J. Food Comp. Anal. 22: 637643.

Kritchevsky, S.B., 1999. $\beta$-Carotene, carotenoids and the prevention of coronary heart disease. Journal of Nutrition, 129: 5-8.

Ktenioudaki, A., F. Butler, and E. Gallagher, 2010. The effect of different mixing processes on dough extensional rheology and baked attributes. J. Science of Food and Agriculture, 90 (12): 20982104.

Lako, J.V., M. Trenerry, N. Wahlqvist, S. Wattanapenpaiboon, and R. Southeeswaran, 2007. Phytochemical flavonols, carotenoids and the antioxidant properties of a wide selection of Fijian fruit, vegetables and other readily available foods. Food Chemistry, 101(4): 1727-1741.

Lavelli, V., C. Peri, and A. Rizzolo, 2000. Antioxidant activity of tomato products as studied by model reactions using xanthine oxidase, myeloperoxidase, and copper-induced lipid peroxidation. Journal of Agricultural and Food Chemistry 48: 1442-1448.

Lee, S.K. and A.A. Kader, 2000. Preharvest and postharvest factors influencing vitamin C content of horticultural crops. Postharvest Biology and Technology, 20: 207-220.

Leonardi, C., P. Ambrosino, F. Esposito, and V. Fogliano, 2000. Antioxidant activity and carotenoid and tomatine contents in different typologies of fresh consumption tomatoes. Journal of Agricultural and Food Chemistry 48: 4723-4727.

Lin, C.H. and C.Y. Chang, 2005. Textural change and antioxidant properties of broccoli under different cooking treatments. Food Chem., 90: 9-15.

Luthria, D.L., S. Mukhopadhyay and D.T. Krizek, 2006. Content of total phenolics and phenolic acids in tomato (Lycopersicon esculentum Mill.) fruits as influenced by cultivar and solar UV radiation. Journal of Food Composition and Analysis, 19: 771-777.

Madhavi, D.L. and D.K. Salunkhe, 1998. Tomato. Handbook of vegetable science and technology. In: Salunkhe, D.K., Kadam, S.S. (Eds.), Production, Composition, Storage, and Processing. Marcel Dekker, New York, pp. 171-201.

Makkar, H.P.S. and K. Becker, 1996. Nutritional value and antinutritional components of whole and ethanol extracted Moringa oleifera leaves. Animal Feed Science and Technology, 63: 211-228.

Martí, R., S. Roselló, and J. Cebolla-Cornejo, 2016. Tomato as a Source of Carotenoids and Polyphenols Targeted to Cancer Prevention. Cancers, 8 (58): 20-28.

Martinez-Valverde, I., S. Periago, J. Maria, G. Provan and A. Chesson, 2002 . Phenolic compounds, lycopene and antioxidant activity in commercial varieties of tomato. J. Sci. Food Agric., 82: 323-330.

Mona-Halaby, A., M. Eman-Elmetwaly and A.A. Aya-Omar, 2013. Effect of Moringa oleifera on serum lipids and kidney function of hyperlipidemic rats. Journal of Applied Science Research, 9 (8): 5189-5198.

N'Dri, D., C. Luca, M. Teresa, S. Francesca, R. Massimiliano, D. Daniele, P. Nicoletta and B. Furio, 2010. Effects of different maturity stages on antioxidant content of ivorian gnagnan (Solanum indicum L.) Berries. Molecules, 15: 7125-7138. 
Nagib, R.M., 2014. Nutritional, Rheological and Biological Evaluation of Pizza Fortified with Moringa oleifera leaves Powder. Bulletin of the National Nutrition Institute of the Arab Republic of Egypt, 6 (43): 46-68.

Nwakalor, C. N. 2014. Sensory evaluation of cookies produced from different blends of wheat and Moringa oleifera leaf flour. International Journal of Nutrition and Food Sciences, 3(4): 307310.

Pacheco de Delahaye, E., P. Jimenez, and E. Perez, 2005. Effect of enrichment with high content dietary fiber stabilized rice bran flour on chemical and functional properties of storage frozen pizzas. Journal of Food Engineering, 68: 1-7.

Pandey, D.K., R. Shekelle, B.J. Selwyn, C. Tangney, and J. Stamler, 1995. Dietary vitamin C and beta carotene and risk of death in middle-aged men. American Journal of Epidemiology 142: 12691278.

Pari, L., M. Karama, A. Kosiñska, A. Rybarczyk, and R. Amarowicz, 2007. Antioxidant activity of the crude extracts of drumstick tree (Moringa oleifera lam.) and sweet broom weed (Scoparia dulcis) leaves, Pol. J. Food Nutr. Sci., 57 (2):203-208.

Picchi, V., C. Migliori, R. Lo Scalzo, G. Campanelli, V. Ferrari, and L.F. Di Cesare, 2012. Phytochemical content in organic and conventionally grown Italian cauliflower. Food Chem., 130: 501-509.

Podsedek, A. 2007. Natural antioxidants and antioxidant capacity of Brassica vegetables: a review. LWT- Food Sci. Technol., 40: 1-11.

Pourcel, L., J.M. Routaboul, V. Cheynier, L. Lepiniec, and L. Debeaujon, 2007. Flavonoid oxidation in plants: from biochemical properties to physiological functions. Trends Plant Sci., 12: 29-36.

Re, R., N. Pellegrini, A. Proteggente, A. Pannala, M. Yang, and C. Rice-Evans, 1999 . Antioxidant activity applying an improved ABTS radical cation decolorization assay. Free Radical Biology and Medicine, 26 (9/10): 1231-1237.

Riboli, E. and T. Norat, 2003. Epidemiologic evidence of the protective effect of fruit and vegetables on cancer risk. American Journal for Clinical Nutrition, 78: 559-569.

Sadler, G., J. Davis, and D. Dezman, 1990. Rapid extraction of lycopene and $\beta$-carotene from reconstituted tomato paste and pink grapefruits homogenates. J. Food Sci., 55: 1460-1461.

SAS 1997. Statistical Analysis System. User's Guide: Statistics, SAS Institute Inc, Gary, Nc., USA.

Sendecor, G.W. and W.G. Cochran, 1997. Statistical Methods; $7^{\text {th }}$ Ed. Oxford and J; B.H. Publishing Co. 504.

Sengey, I., Abu, J. and D. Gernah, 2012. Effect of M. oleifera leaf powder supplementation on the quality characteristics of wheat bread. Intercontinental Journal of Food Science and Nutrition, 1 (1): $1-5$.

Shewry, P. R., A. S. Tatham, F.Barro, P. Barcelo and P. Lazzeri, 1995. Biotechnology of bread making, unraveling and manipulating the multi-protein gluten complex. J. Biotech., 13: 11851190.

Shimada, Y. and S. Ko, 2006. Quantitative Determination of Ascorbic Acid in Vegetables by High Performance Liquid Chromatography. Chugokugakuen J., 5: 13-16.

Sies, H. 1997. Oxidative stress: oxidants and antioxidants. Exp Physiol.; 82 (2): 291-295.

Skendi, A., C. Biliaderis, M. Papageorgiou and M. Izydorczyk, 2009. Effects of two barley $\beta$-glucan isolates on wheat flour dough and bread properties. Journal of Food Engineering, 91 (4): 594601.

Slimestada, R. and M. Verheulb, 2009. Review of flavonoids and other phenolics from fruits of different tomato (Lycopersicon esculentum Mill.) cultivars. J. Sci. Food Agric., 89: 1255-1270.

Tang, G. 2010. Bioconversion of dietary pro-vitamin A carotenoids to vitamin A in humans. Am. J. Clin. Nutr., 91: 1468-1473.

Thompson, K.A., M.R. Marshall, C.A. Sims, C.I. Wei, S.A. Sargent, and J.W. Scott, 2000. Cultivar, maturity and heat treatment on lycopene content in tomatoes. Journal of Food Sciences 65: 791795.

Tokuşoğlu, Ö., M.K. Ünal, and Z. Yildırım, 2003 . HPLC-UV and GC-MS Characterization of the Flavonol Aglycons Quercetin, Kaempferol and Myricetin in Tomato Pastes and Other TomatoBased Products. Acta Chromatographica, 13: 196-207. 
Trumbo, P., A.A. Yates, S. Schlicker and M. Poos, 2001. Dietary Reference Intakes for vitamin A, vitamin $\mathrm{K}$, boron, chromium, copper, iodine, iron, manganese, molybdenum, nickel, silicon, vanadium and zinc. J. Am. Diet. Assoc., 101: 294-301.

Valko, M., C.J. Rhodes, J. Moncol, M. Izakovic and M. Mazur, 2006. Free radicals, metals and antioxidants in oxidative stress-induced cancer. Chem. Biol. Interact., 160: 1-40.

Velioglu, Y.S., L. Mazza, L. Gao and B.D. Oomah, 1998. Antioxidant activity and total phenolics in selected fruits, vegetables and grain products. J. Agric. Food Chem., 46: 4113-4117.

Vinson, J.A., Y.A. Dabbagh, M.M. Serry and J. Jang, 1995. Plant flavonoids, especially tea flavonols, are powerful antioxidants using an in vitro oxidation model for heart disease. Journal of Agriculture and Food Chemistry, 43: 2800-2802.

Weisburger, J.H., 1998. Evaluation of the evidence on the role of tomato products in disease prevention. Proceedings of the Society of Experimental Biology and Medicine 218: 140-143.

World Cancer Research Fund, 1997. Food, Nutrition and the Prevention of Cancer: A Global Perspective. American Institute for Cancer Research, Washington, DC, USA.

Yousaf, S., 2001. Development of dough mix for deep dish pizza. Dept. Food Tech., Univ. Agric., Faisalabad (Pakistan).

Zuo, Y., H. Chen, and Y. Deng, 2002. Simultaneous Determination of Catechins, Caffeine and Gallic acids in green, Oolong and Black tea using HPLC with a Photodiode Array Detector. Talanta, 57: $307-316$. 